\title{
A disposable glucose biosensor based on drop-coating of screen-printed carbon electrodes with magnetic nanoparticles
}

\author{
Bo-Wen Lu, Wen-Chang Chen* \\ Department of Chemical Engineering, National Yunlin University of Science and Technology, 123, University Road, Sec. 3, \\ Douliou, Yunlin 64002, Taiwan, ROC
}

Available online 6 March 2006

\begin{abstract}
Magnetic $\mathrm{Fe}_{3} \mathrm{O}_{4}$ nanoparticles $\left(\mathrm{Nano}-\mathrm{Fe}_{3} \mathrm{O}_{4}\right)$ were prepared by co-precipitation method and a disposable glucose biosensor was fabricated by drop coating of ferricyanide (Ferri)-Nano- $\mathrm{Fe}_{3} \mathrm{O}_{4}$ mixture onto the surface of screen-printed carbon electrodes (SPCEs), and then by layering-on glucose oxidase (GOD). The electrochemical characteristics of modified SPCEs were analyzed by cyclic voltammetry (CV), electrochemical impedance spectroscopy (EIS) and chronoamperometry (CA). The glucose biosensors exhibit a relatively fast response $(<15 \mathrm{~s})$ and high sensitivity (ca. $\left.1.74 \mu \mathrm{AmM}^{-1}\right)$ with a wide linear range up to $33.3 \mathrm{mM}\left(600 \mathrm{mg} \mathrm{dL} \mathrm{m}^{-1}\right)$ of glucose. (C) 2006 Published by Elsevier B.V.
\end{abstract}

Keywords: $\mathrm{Fe}_{3} \mathrm{O}_{4}$ nanoparticles; Screen-printed carbon electrodes $\left(\mathrm{SPCE}_{\mathrm{S}}\right.$ ); Electrochemical impedance spectroscopy (EIS); Glucose biosensor

\section{Introduction}

Since biosensors allow a wide range of transduction technology to be used, they have advantage over ordinary chemical sensors. Among them, the glucose biosensor has been widely used as a clinical indicator of diabetes and in the food industry for quality control $[1,2]$.

Nanomaterials are expected to exhibit attractive properties in the applications of electroanalysis [3]. Their electrocatalytic activity toward many biomolecules has been attributed to their ultra-small size, high surface area and good biocompatibility [4,5].

Recently, magnetic $\mathrm{Fe}_{3} \mathrm{O}_{4}$ nanoparticles $\left(\mathrm{Nano}-\mathrm{Fe}_{3} \mathrm{O}_{4}\right.$ ) have gained an increasing interest in the applications in biotechnology and medicine. Due to their biocompatible catalytic activity and low toxicity, it would be promising to utilize Nano- $\mathrm{Fe}_{3} \mathrm{O}_{4}$ for biosensor applications [6]. Furthermore, it was reported that the immobilization of enzymes on magnetic nanoparticles could potentially result in unique properties of bioactive particles, such as increased enzyme activity due to the increased surface area of nanoparticles, and good dispersion in the analyte solution

\footnotetext{
${ }^{*}$ Corresponding author. Tel.: + $88655342601 x 4621$; fax: +88655312071

E-mail address: chenwc@yuntech.edu.tw (W.-C. Chen).
}

leading to rapid contact between the enzyme and its substrate and reduction of mass-transfer limitations [7].

In this study, magnetic Nano- $\mathrm{Fe}_{3} \mathrm{O}_{4}$ were prepared by co-precipitation method [8] and a disposable glucose biosensor with high sensitivity was fabricated by dropcoating of mixture of ferricyanide (Ferri)-Nano- $\mathrm{Fe}_{3} \mathrm{O}_{4}$ onto the surface of screen-printed carbon electrodes (SPCEs), and glucose oxidase (GOD) was then layered on. The electrochemical properties of the modified SPCEs were characterized by electrochemical impedance spectroscopy (EIS), cyclic voltammetry (CV) and chronoamperometry (CA). Details of the biosensor preparation, characterization and application for glucose determination are described and discussed.

\section{Experimental}

GOD (EC1.1.3.4, 179,000 $\left.\mathrm{Ug}^{-1}\right)$ and $\beta$-D-glucose were purchased from Sigma (St. Louis, MO) and hexacyanoferrate (III) (Ferri) from Merck. All other chemicals were the analytic grade reagents and used without further purification.

Magnetic Nano- $\mathrm{Fe}_{3} \mathrm{O}_{4}$ were prepared by coprecipitating $\mathrm{Fe}^{2+}$ and $\mathrm{Fe}^{3+}$ ions by ammonia solution and treating under hydrothermal conditions [6]. 
Disposable glucose biosensors were fabricated by dropcoating with $10 \mu \mathrm{L}$ of solution containing Ferri-Nano$\mathrm{Fe}_{3} \mathrm{O}_{4}$ mixture onto the surface of SPCEs, and allowed to dry at $40^{\circ} \mathrm{C}$ for $15 \mathrm{~min}$. Then $10 \mu \mathrm{L}$ of GOD solution was layered on SPCEs and dried at $40{ }^{\circ} \mathrm{C}$ for $15 \mathrm{~min}$, and the biosensor test strips were ready for use.

$\mathrm{CV}$ and CA experiments were performed with CHI 611A electrochemical workstation (CHI Instrument, USA). EIS analyses were performed at the open-circuit potential with Autolab PGSTAT12 (Eco chemie, B.V., The Netherlands) controlled by GPES 4.9 softwares, and the impedance spectra were recorded in the frequency range $0.1-100 \mathrm{kHz}$ by using a sinusoidal excitation signal (single sine) with an excitation amplitude of $10 \mathrm{mV}$. The impedance spectra were expressed with the Nyquist plot. A commercial software (FRA 4.9) was employed for simulating experimental impedance data with an electronic equivalent circuit model.

\section{Results and discussion}

The diameter of the semicircle in the EIS equals the electron transfer resistance $\left(R_{\mathrm{ct}}\right)$. This resistance controls the electron-transfer kinetics of the redox probe at the electrode interface [9]. Results show that $R_{\mathrm{ct}}$ value increases from $560 \mathrm{k} \Omega$ (bare SPCEs, Fig. 1, curve b) to $2856 \mathrm{k} \Omega$ (curve a) as GOD is layered on the surface of SPCEs, and decreases as loading of Nano- $\mathrm{Fe}_{3} \mathrm{O}_{4}$ increases (curves c-f: $455,303,236$, and $189.2 \mathrm{k} \Omega$, respectively). It is suggested that GOD layer acts as a barrier for the electron transfer between the electrode surface and the redox probes in the solution. Moreover, Nano- $\mathrm{Fe}_{3} \mathrm{O}_{4}$ not only provide the hydrophilic surface, but also act like nanoscale electrodes in promoting the electron transfer between the electroactive Ferri/Ferro species and SPCEs surface due to highly permeable structure [3].

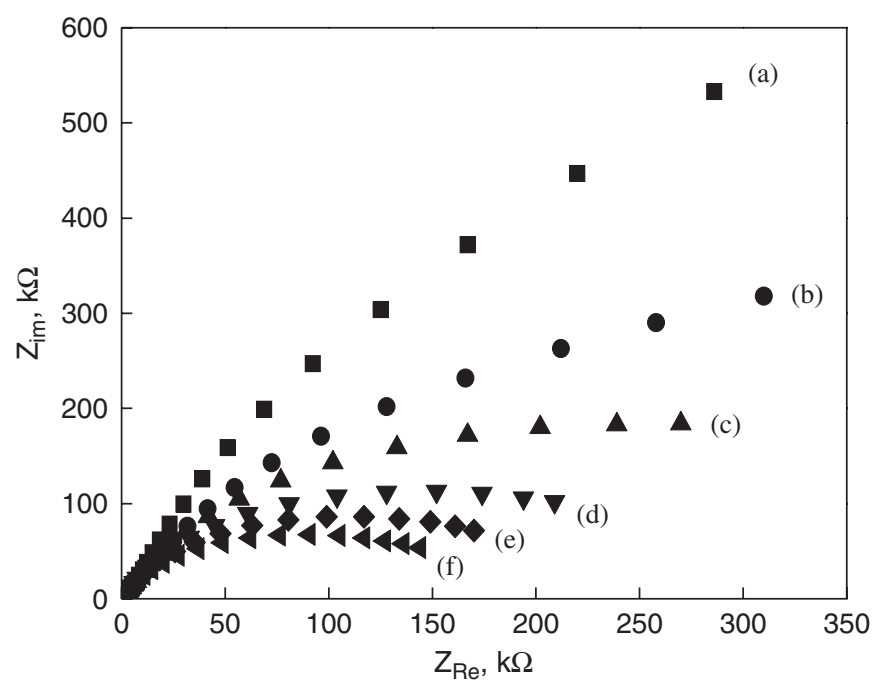

Fig. 1. EIS of (a) GOD/Ferri-coated SPCEs, (b) Ferri-coated SPCEs, and

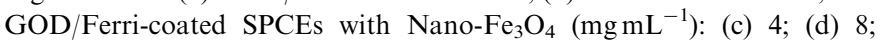
(e) 12 ; (f) 16 .
CVs of a redox probe are valuable and convenient tools to monitor the behavior changes during the electrodemodified process. In this work, the response characteristics of various glucose biosensors using Ferri as a redox probe were determined by CV (Fig. 2). A remarkable increase in response currents to glucose could be observed after modifying with $16 \mathrm{mg} \mathrm{mL}^{-1} \mathrm{Nano}-\mathrm{Fe}_{3} \mathrm{O}_{4}$ (curve b). The modified Randles-Sevčik equation describes the dependence of peak current response $\left(i_{\mathrm{p}}\right)$ on scan rate, electrontransfer rate constant, electro-active area and surface concentration of redox probe. Thus, results might suggest that $\mathrm{Nano}-\mathrm{Fe}_{3} \mathrm{O}_{4}$ not only provided the necessary conduction pathways to enhance the electron transfer between the analyte and electrode surface, but could also act like



Fig. 2. Response characteristics from $\mathrm{CV}$ of $10 \mu \mathrm{L}$ glucose $\left(250 \mathrm{mg} \mathrm{dL}^{-1}\right)$ at (a) GOD/Ferri-coated SPCEs, and (b) GOD/Ferri-Nano-Fe $\mathrm{O}_{4}$-coated SPCEs. Scan rate $=0.01 \mathrm{~V} \mathrm{~s}^{-1}$.

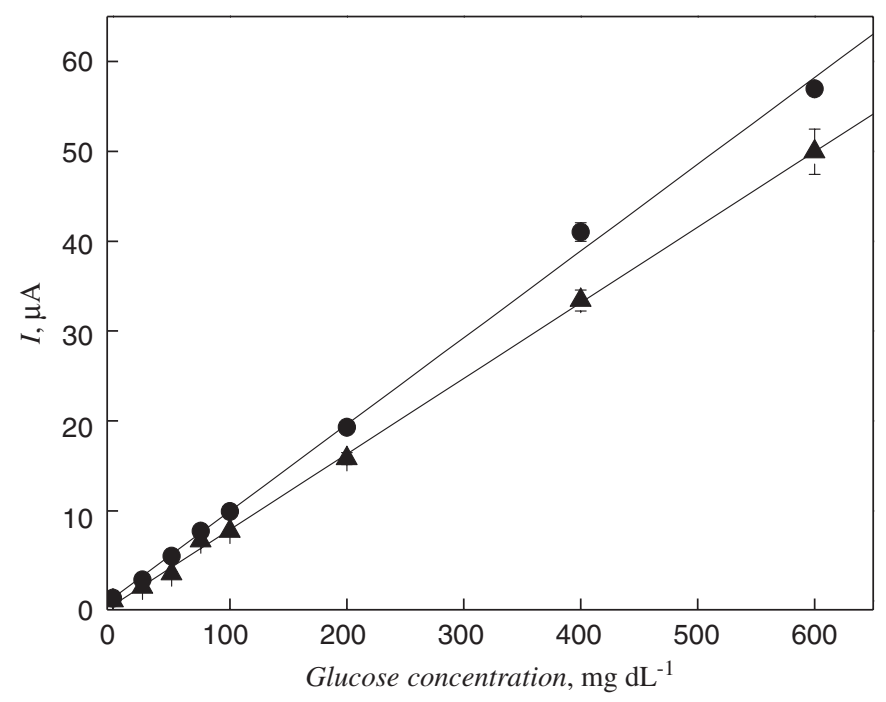

Fig. 3. Calibration plots obtained from $\mathrm{CA}$ at $(\bullet)$ GOD/Ferri-Nano$\mathrm{Fe}_{3} \mathrm{O}_{4}$-deposited, and $(\boldsymbol{\Lambda}) \mathrm{GOD} /$ Ferri-deposited SPCEs. 
nanoscaled electrode for the biomolecules. Moreover, the Nano- $\mathrm{Fe}_{3} \mathrm{O}_{4}$ can sorb iron-cyanide complexes, which increase surface concentration of redox probe [10], and hence an increase in response current could be expected.

The calibration curve of the Nano- $\mathrm{Fe}_{3} \mathrm{O}_{4}$-modified SPCEs glucose biosensor was taken from the data obtained by $\mathrm{CA}$ with varying glucose concentration $(\mathrm{pH}$ 7.0) at room temperature (as shown in Fig. 3). The response time (reaching $95 \%$ of the maximum response) was less than $15 \mathrm{~s}$ (data not shown), which indicated a fast diffusion process and a high activity of GOD modified by Nano$\mathrm{Fe}_{3} \mathrm{O}_{4}$. The linear response range of glucose concentration for the Nano- $\mathrm{Fe}_{3} \mathrm{O}_{4}$ biosensor is up to $600 \mathrm{mg} \mathrm{dL}^{-1}$ with a higher sensitivity (ca. $1.74 \mu \mathrm{A} \mathrm{mM}^{-1}$ ). The wide linearity of the biosensors can be explained by an excessively high concentration of Ferri used, which may overcome the relatively slow kinetics of GOD oxidation by Ferri.

\section{Conclusions}

In this study, we have introduced an approach for fabrication of glucose biosensor based on drop-coating
GOD on SPCEs modified with Ferri-Nano- $\mathrm{Fe}_{3} \mathrm{O}_{4}$ mixture. $\mathrm{CV}, \mathrm{CA}$, and EIS techniques were used to investigate the electrochemical characteristics of the modified SPCEs. It was found that the resulting glucose biosensor exhibited a fast response $(<15 \mathrm{~s})$ with high sensitivity and good repetition.

\section{References}

[1] F.M. Tian, G.Y. Zhu, Anal. Chim. Acta 451 (2002) 251.

[2] J.J. Xu, Z.H. Yu, H.Y. Chen, Anal. Chim. Acta 463 (2002) 239.

[3] E. Katz, I. Willner, J. Chem. Electroanal. 16 (2004) 19.

[4] R.S. Chen, W.H. Huang, H. Tong, Z.L. Wang, J.K. Cheng, Anal. Chem. 75 (2003) 6341.

[5] F. Valentini, A. Amine, S. Orlanducci, M.L. Terranova, G. Palleschi, Anal. Chem. 75 (2003) 5413.

[6] D.H. Chen, M.H. Liao, J. Mol. Catal. B Enzyme 16 (2002) 283.

[7] L.M. Rossi, A.D. Quach, Z. Rosenzweig, Anal. Bioanal. Chem. 380 (2004) 606.

[8] S. Bucak, D.A. Jones, P.E. Laibinis, A. Hatton, Biotechnol. Progr. 19 (2003) 47.

[9] E. Katz, I. Willner, Electroanalysis 15 (2003) 913.

[10] T. Rennert, T. Mansfeldt, J. Plant Nutr. Soil Sci. 164 (2001) 651. 